MYKOLO ROMERO
UNIVERSTIEAS

\title{
PROFESSIONAL AUTONOMY OF FRENCH HIGHER EDUCATION LANGUAGE TEACHERS: AT THE CROSSROADS OF SOCIAL SCIENCES AND HUMANITIES
}

\author{
Nadia Yassine-Diab, Nolwena Monnier \\ University Paul Sabatier (Toulouse III) \\ Research Laboratory LAIRDIL \\ University Institute of Technology, Computing Department (Informatique) \\ 133B Avenue de Rangueil, BP 67701 \\ 31077 Toulouse Cedex 4, France \\ Telephone: (+33 6) 15137849 \\ E-mail: nadia.yassine-diab@iut-tlse3.fr \\ University Institute of Technology, Business Department (TC), \\ 115F route de Narbonne, 31077 Toulouse Cedex, France \\ Telephone: (+33 05) 62258141 \\ E-mail: nolwena.monnier@iut-tlse3.fr
}

Received 12 April, 2013; accepted 12 July, 2013

doi:10.13165/SMS-13-5-3-09

Abstract. The French university system is said to give quite a lot of autonomy to teachers as opposed to secondary education. The LRU law (2007), which modified the status of French universities and made them autonomous, may impact teachers' professional autonomy on the long-term. This led us to conduct a pilot study and then a national survey to know more about this topic. In this paper, we would like to focus on the qualitative aspect of this survey. Through this national survey, we asked higher education language teachers to define what professional autonomy meant for them and to what extent it could influence their teaching. This allowed us to pinpoint some features about team work, teachers/students relations and 
teachers' assessment. We will thus focus on what teachers' professional autonomy is, what can reduce it and what can enhance it at the crossroads of Social Sciences and Humanities.

Keywords: autonomy, higher education, language teaching, national survey, professional training.

\section{Introduction}

Student autonomy has been a regular research theme in language didactics for several years. Teacher's Professional Autonomy has been far less studied and is thus an innovative research area. The Lairdil research $l^{1} b^{1}$ has decided to focus on this topic at the crossroads of sociology, pedagogy and professional training. The long-term aim of this research is to improve Higher Education language teachers' professional training in France. In a changing university environment, the question is indeed crucial. The 2007 LRU law ${ }^{2}$ aimed to give more financial independence and autonomy to French universities for them to enhance their international attractiveness. Even if they remain state/public institutions, French universities have experienced deep transformations and are still doing so. In such a context, Teachers' Professional Autonomy (TPA) could be challenged, especially as it has usually been taken for granted until now. In the next few years, it will be interesting to examine this point to see to what extent this law has influenced TPA.

We conducted in a pilot study in 2010-2011 and administered questionnaires to about 30 colleagues. We primarily dealt with quantitative results which led to a first oral presentation in May 2011 during the annual conference of the $\mathrm{SAES}^{3}$ in the Language Didactics workshop. Discussions with colleagues brought us to a second, more complete questionnaire including open questions, thanks to which we had the opportunity to carry out a qualitative analysis in 2011-2012. We collected a little more than a hundred questionnaires nationwide. This paper presents the results of this French national survey which aimed at defining TPA from a Higher Education Teachers' perspective and at identifying potential brakes and constraints to TPA in order to offer more relevant training to develop TPA as a professional skill. We will start with a few theoretical definitions of autonomy.

1 LAIRDIL research laboratory [interactive]. [ accessed on 11-08-2013]. <www.lairdil.org>.

2 Loi relative aux Libertés et Responsabilités des Universités (LRU).

3 Société des Anglicistes de 1'Enseignement Supérieur (French Higher Education English Teachers' Society). [ accessed on 11-08-2013]. <www.saes.org > . These quantitative results are to be published in the International Journal of Organizational Analysis, 22(2), in 2014. 


\section{Autonomy}

\subsection{Autonomy, independence and professionalism}

Since the 1990's, the word "autonomy" has appeared more and more in research in didactics. This term first referred to student autonomy directly linked to the development of TICE (Technologies of Information and Communication in Education), such as online education, e-learning, blended learning, language centers and multimedia tools. Several books were published on student autonomy and teachers' role(s), which consist in helping learners to become autonomous and more responsible regarding their own linguistic learning. The word "autonomy" is then often associated with "selfsufficiency". These two notions are understood as qualities learners need to master and know how to put into practice.

As far as the fact of being professional is concerned, Freidson underlines that the word "professionalism" is very difficult to define in our society: "The word professionalism has become difficult to evaluate because the term is frequently used as a shibboleth - that is, a word used as a slogan that lacks real meaning"4. However, he stresses that this very professionalism encourages innovation and intellectual stimulation: "professionalism [...] provides a milieu which encourages intellectual innovation - the development of new knowledge, skills, and ideas"s.

As it has been previously said, so far Higher Education Teachers' Professional Autonomy has been scarcely studied. We chose to concentrate on language teachers of any gender, administrative status, university or years of experience in French universities. Our research protocol lies on "action-research" as defined by Nunan: "a systematic process of inquiry consisting of three elements or components: (1) question, problem, or hypothesis, (2) data, (3) analysis and interpretation of data"6. In 1997, Benson and Voller in Autonomy and Independence in Language Learning defined autonomy as the "right for a person to determine freely ${ }^{7}$ the rules to which one submits oneself". Equally, Young, quoted by Benson in his paper "'Teachers' and 'Learners' Perspectives on Autonomy" in Lamb and Reinders's book, highlights this freedom as being necessary to autonomy: "Autonomy does not [...] imply freedom of action on any given occasion, but rather a more general idea that the individual should 'freely direct the course of his or her own life" "9. According to Little, Teachers' Professional Autonomy does not seem to be linked to this notion of freedom, on which we will come back, but imply other aspects as well, such as the ability to have a global view

Freidson, E. Professionalism: The Third Logic. Cambridge and Oxford: Polity, 2001, p. 198.

Ibid., p. 176.

6 Nunan, D. Research Methods in Language Learning. Cambridge: Cambridge University Press, 1992, p. 3.

7 We highlighted this word.

8 Benson, O. and Voller, P. Autonomy and Independence in Language Learning. London: Longman, 1997, p. 166.

9 Lamb, T. and Reinders, H. Learner and Teacher Autonomy: Concepts, Realities and Responses. Amsterdam/ Philadelphia: John Benjamins Publishing Company, 2008, p. 17. 
of the tasks and make decisions and manage a self-sufficient and autonomous practice. Little, quoted by Gavrilyuk in "Development of Professional Autonomy in University Teachers", states that "'teacher's capacity to engage in self-directed teaching', including 'detachment, critical reflection, decision-making and independent action'"'10.

As we can understand from these different quotations, the perception and definition of professional autonomy depend on numerous factors and remain quite blurry. That seems to be true for the teachers as well, who agreed to answer our questionnaire designed for this study. Some humorously regretted that "even Google does not give a clear definition of the notion". Another colleague declared that "[It's] a very blurred concept for me. No one has ever talked to me about it in my professional environment". There is no doubt, regarding the answers given, that the majority of the authors' colleagues were interested in this theme. Many of them asked us to send them our results of the study and said that they "would like to know more".

When we took a closer look at the definition suggested by our colleagues, we noticed opposite trends. This helped us determine how we would tackle this concept. We decided to focus on the following topics in this paper: working habits, the notion of choice and pedagogical freedom, and time management. We could distinguish three trends: one is centered on the learners, one on the teachers and the last is a mixed trend. We, eventually, paid attention to what can be called the "pleasure to teach". We asked our colleagues which elements could hamper this very pleasure and its link with their professional autonomy as well as its influence on it. After our colleagues' personal definitions, we took a closer look at the literature on the topic.

\subsection{Autonomy: etymology and definitions}

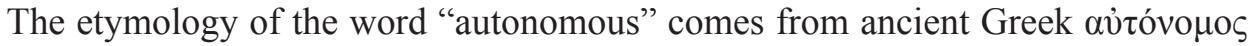
("autonomos"), which means "who/which is governed by his/her/its own rules". This definition corresponds to a certain number of our colleagues' definitions. Thus, one of them declares that professional autonomy is for him/her: "designing, preparing and managing my classes on my own". Paradoxically, according to other colleagues, working in an isolated way can lead to a "feeling of solitude". Another one underlines that "the danger to be on your own, with no safeguard, no reference, and the counterproductive consequences which come with it". But in fact, most of our colleagues praised teamwork which would prevent an "unavoidable professional stagnation". Thus, professional autonomy is "deciding as part of a team" in the structure it gives. The "consultation" and the "collaboration with colleagues" in a "pedagogic team" are vital elements. To sum up, "one needs to work as part of a team". Although we could have expected teamwork to be seen as an obstacle to professional autonomy, we noticed that it is not the case as communication leads the way on potential compromises and renunciations necessary to go forward in a common direction. Nevertheless, a few colleagues pinpoint the difficulty to work as a part of a team as it can be a "source of tensions". One of

10 Gavriliuk, O. Development of Professional Autonomy in University Teachers. Paper presented at Proceedings of Advances in Business-Related Scientific Research Conference, 8-10 November, Olbia, Italy. 2010, p. 2. 
them, however, admits that teamwork allows a larger coherence in front of learners. Teamwork needs at least a "similar vision of work" to be efficient. Acertain flexibility and an ability to adapt are also compulsory. We will detail these different notions further down in this paper and will focus now on freedom.

\section{Freedom and Brakes}

\subsection{Autonomy and pedagogic freedom}

No matter how one works - on one's own or as part of a team, for our colleagues professional autonomy mainly corresponds to two key words: "freedom" and "choice". Many of them evoke "pedagogic freedom", whether it affects the choice of the content and pedagogic objectives, the opportunity of making them evolve their variety and choice and/or the elaboration of teaching material and the pedagogic methods used. One colleague states that this aspect is "fundamental to [him/her]". We can notice that only one of our colleagues tackle the question of in class pedagogical practice. This very autonomy seems to be obvious for a large majority of the colleagues. One of them notes the importance of "adapting the content" as well as "inside constraints fixed by the program". In fact, different restraints regularly appear in the different testimonies. We distinguished three types of frameworks, which sometimes reflected what our colleagues said: pedagogic, external and institutional, as one declared that "autonomy is not doing just what we want with no pedagogic objective". A pedagogic framework is set in most cases, whether it is defined by a National Curriculum (like in the University Institutes of Technologies) made up under the teaching teams' supervision or because it is established in a department by a specific coordinator. Some alert on the risk of "a too coercing program" or of "a pre-defined program which must be followed at any cost". Someone even evokes the risk of a "national exam". What does he/she mean by that as each university defines its courses and evaluation means on its own? Does he/she evoke certain certifications, such as the CLES ${ }^{11}$ or the TOEIC ${ }^{12}$ ? In fact, different French engineering schools require their students to validate a minimum TOEIC score in order to graduate with Masters'. In the same way, certain business schools require a fixed TOEIC score as a criterion of selection. This leads to a certain pressure from learners on teachers to prepare the former to these specific exams. On the other side, we can remember a recent initiative from the French Ministry for Higher Education and Public

11 Higher Education Certificate of Competences in Foreign Languages. Accredited by the Minister of National Education, and offered for free to students in an increasing number of French universities. It is offered in several languages and on three different levels. [interactive]. [ accessed on 11-08-2013]. <http:// www.certification-cles.fr/>.

12 Test Of English for International Communication. Offered by the private organization ETS which certifies a certain number of schools as exam centers. There is a fee to pay and it gives a score out of 990. [interactive]. [accessed on 11-08-2013]. <http://www.ets.org/toeic/>. 
Research can be recalled which aimed to impose a CECRL ${ }^{13} \mathrm{~B} 2$ level validated to all Masters' students, especially those training to become primary school teachers. This law has been postponed until now, but this could have created some more constraints cutting into Teachers' Professional Autonomy. We would now like to turn to another type of pressure, i.e. institutional pressure.

\subsection{Autonomy and institutional pressure}

Institutional pressure was often alluded to in questionnaires. This factor can express itself in different ways. Even if it is not yet planned, the fear of teaching inspections is regularly alluded to in testimonies. This may be due to the fact that quite a large number of colleagues come from secondary education, where they have already lived that type of evaluation and they know how stressful it can be to be judged on a single one-hour class every 5 to 10 years. The term "hierarchy" appears regularly, as well: a colleague even used the expression "directives from top management", which shows the rift that can exist between teachers exposed to everyday teaching reality and their top management whose choices can sometimes be too theoretical. A colleague underlines the "increasing pressure linked to having to systematically justify everything to hierarchy". This wording seems strong to us . Indeed, it indicates a negative perception of hierarchy, which would imply a tendency to put teachers in a child's position to endlessly challenge their skills and authority. This crisis of confidence between the teachers and their hierarchy is truly problematic as several colleagues claim that "being supported by [our] hierarchy in [our] choices" is essential". They need "[their] university to trust [them] to work at best". They want to "benefit from an open and benevolent attitude [...] aiming at the quality of their teaching plans and methods". As one of the questioned teachers says, "our administration must be serving the actions suggested and managed by a competent and responsible teacher, respectful of and implicated in the collectivity". The next section is devoted to another kind of institutional pressure, i.e. the matter of over-evaluation.

\subsection{Autonomy and over-evaluation}

Over-evaluation is worrying our colleagues. One of them highlights the risk of drifting into something wrong: "I would not like me to be asked to evaluate students very often as it would spoil the pedagogical dimension of my teaching and would consequently decrease my preparation and teaching time". The problem of "overevaluation" matches both students' and teachers' dimensions for whom "a systematic evaluation of everything [they] do (teaching, research...)" would be a hindrance to

13 Common European Framework of Reference for Languages [interactive]. [last accessed on 11-08-2013]. $<$ http://eduscol.education.fr/cid45678/cadre-europeen-commun-de-reference.html >; an explanation in English can be found here: [interactive], [ accessed on 11-08-2013].

$<$ http://www.coe.int/t/dg4/linguistic/source/framework_en.pdf $>$; Wikipedia gives the following definition: [accessed on 11-08-2013]. <http://en.wikipedia.org/wiki/Common_European_Framework_of_Reference_for_Languages $>$. 
professional autonomy. Autonomy respects this relation, in which the institution as much as the individual must get involved. The gratitude of the institution is a capital component, which, for some, goes through a financial recognition up to the diplomas: "Professional Autonomy is the reason why we accept to be underpaid regarding the level of study necessary to teach at university". Others explain that they need the recognition of their working time and the investment outside teaching hours, which leads us to the question of time management.

\subsection{Autonomy and time management}

«Managing quite freely one's own time» is a vital characteristic of Teachers' Professional Autonomy. This latitude and flexibility to manage one's working time («annual timetable, time to prepare classes and time to correct exams and essays») must not be challenged or questioned by the fact of «justifying the number of hours spent to prepare modules». This hidden work, the «hidden part of the iceberg» if we may call it so, should not be underestimated. Many colleagues admit that they need a greater recognition for all the work they do in addition to teaching. Administrative tasks are regularly mentioned by colleagues who year after year record more responsibilities which are added to research and/or teaching activities which are the heart of Higher Education Teachers' work. These tasks clearly encroach upon a «freedom necessary to the practice of a time-consuming job which needs a global view». These administrative tasks impact teachers' work. The heaviness of these tasks is explained by the fact that «[teachers] have not been trained for that» and they «consequently take time on the work for which [they] are competent». These activities are very specific to Higher Education where language teachers were not specifically trained. This extra work, scarcely properly valued, hinders professional autonomy while imposing time-consuming extra difficulties. Indeed, teaching induces not only a preparation and then execution time, but also a pedagogical reflection which leads to an often relevant remediation, as one of our colleagues stated: «I would even have more pleasure to teach if I could spend more time on my practice and improve the pedagogic aspect of my modules». This notion of pleasure is wide and led us to devote a part of our questionnaire to this specific topic, as we shall see in our third and last part of the article. Before doing so, we will analyze the three visions of TPA that we have determined.

\section{Three Visions of Professional Autonomy}

While analyzing questionnaires, we could distinguish three main trends, both antinomic and complementary. $54 \%$ of our colleagues have a vision of their professional autonomy which is centered on teachers, $33 \%$ centered on learners and $13 \%$ have a mixed approach. 


\subsection{Autonomy and teaching adaptation to students' needs}

One of our colleagues clearly asserts that "we need to think about students first". For several of them, the first requirement is to "answer to students" needs". These needs can be professional as well as linguistic ones. One of our colleagues considers that professional autonomy consists in "setting up one's own modules while catering to students' needs in order to prepare them as best we can for the professional world". This aspect is a very important one, especially in IUTs, where one needs to "design, in the framework of the National Curriculum ${ }^{14}$, teaching contents [...] adapted to students in relation with targeted professional objectives". Another colleague told us about "well-reasoned choices in terms of contents and demands in relation with the specific needs of learners", needs which can also be the linguistic ones. The key word seems to be "adaptation". In fact, one needs to not only "be adaptable to the level and rhythm of students", but also to be free to "adapt one's teaching (pedagogic contents and practices, rhythm, etc.) to the characteristics (level, curiosity, imagination, etc.) of the group of students one teaches". This adaptation could have been perceived as frustrating and constraining, forcing teachers to renounce the ideal image of the perfect class. Actually, we realized that it is rather a surprisingly essential aspect of TPA that teachers praise. For some, the priority in a language course is linked to the very essence of the linguistic subject. One colleague explains that for him/her the "mastering of an approved and efficient methodology to succeed in developing real communication skills in students" is necessary. Another one insists on the fact of "training students according to the needs of the discipline". The notion of adaptation does not always seem to be the key point for colleagues, as for some the subject taught prevails over the targeted public (specialization and level) and the institution and the type of training, but they all seem to value the ability to invest oneself professionally.

\subsection{Autonomy and investment}

For other colleagues, professional autonomy rests in "being free to invest oneself in different projects and domains according to one's career" and to "elaborate projects, $[\ldots]$ make decisions in one's domain of expertise, [...] taking responsibility for the whole of a problem respecting a certain deontology". The problem is not the investment itself, but to remain free to do it as much as one wants. Finally, one colleague insists on the importance of "having fun through the themes treated and the way to do it". This notion of pleasure is linked for others to a consideration for students. "Choosing themes and teaching material which I like while corresponding to students' needs" perfectly shows that the pleasure a teacher takes is as important as students' needs and that in this case, both participate in Teachers' Professional Autonomy. Now, what about the notion of pleasure?

14 The new version of the National Curriculum. (PPN is regularly modified and adapted to the market and professional needs. The latest version will be enforced in September 2013 in all the French University Institutes of Technology. 


\subsection{Autonomy and pleasure}

To the question "Do you enjoy teaching? Comment..." several key words were highlighted in questionnaires: "conviction", "passion", "vocation", "commitment", "pride", "identity" and "dream". In this way, one colleague affirmed: "I chose this job by conviction and I' $m$ fond of teaching". Some others recognized they still "burn with enthusiasm" and "would not consider doing anything else". For others, the relation to work seems very visceral and is fully part of their identity: "Teaching is in my blood. It's as simple as that". One colleague confides that his/her vocation is a youthful dream and adds: "My dream comes true each time I enter a classroom and I'm lucky to be able to do the job I like because it's rare". But what does nourish this passion? The answer may lie in the relation and the interaction with students. Indeed, more than one teacher stresses this aspect. One of them declares: "Students are the best part of my job". They evoke a "stimulating" exchange with students and admit that "teaching sessions are breaths of pure air". The contact and interaction with students "harmoniously complete the individual and lonely exercise of preparing modules and doing research". If a confident relation with the institution is necessary, one colleague notes that "when a confident relation takes place [with students] and we have the feeling of succeeding in conveying something, it's just magic". Another confirms that he/she has "the feeling of being useful and to be exactly where he/she is supposed to be". Another one agrees to that point, as he/she finds his/her job "rewarding" and appreciates the fact that people can "rely on" him/her, whether it is to notice "visible [...] progress" ("an important satisfaction") or to coach students more globally on their project: "I like contacts with students, see them evolve, encourage them, boost them to study or complete an internship abroad". Nevertheless, there lies a double challenge. On the one hand, teachers consider they need to encourage students, so they can go beyond their prejudices, as one of the colleagues explains, "as far as English is concerned, students come with much a priori from secondary school and trying to make them change their mind is really pleasant". On the other hand, students can also be a driving force for change and they "[push] to improve the class level and diversify approaches", allowing us to avoid routine. Finally, the colleagues and/or the professional network seem to contribute in an efficient way to the pleasure teachers get from work, as one of them declares: "I appreciate the contact and exchanges with colleagues a lot. Several of them are now close friends". If our colleagues praise their own pleasure, what about students? Students' needs seem to be very important for the people questioned. Are students supposed to be happy to learn because they have satisfied their needs? Nevertheless, this image, which seems ideal, is to be nuanced due to different constraints.

\subsection{Autonomy and constraints}

Several colleagues regret a deterioration of their working conditions, whether they are linked directly to students or to material circumstances, as some colleagues note, «students' level is no better [...], they are more and more assisted and less and less responsible». Their lack of motivation seems to be directly linked to teachers' 
motivation, as one of them explains as follows: «their lack of motivation degrades my own enthusiasm to teach». Another one notices that «certain students' childishness and lack of investment are major concerns». Another colleague regrets «not to be able to help more students who often come from vocational secondary education diplomas». In fact, several national objectives ( $80 \%$ of students should get a secondary education diploma (for instance, French Baccalauréat), and 50\% of them should get a Degree) have made the university students' profiles evolve. The increase of student numbers, the diversity of backgrounds and the heterogeneity of levels are interlocutory to students ${ }^{15}$ as well as to teachers. As one of the colleagues explains, «[...] material conditions can be a problem, especially the size of groups. Dealing with a group of thirty students in a language class hampers my professional autonomy, i.e. my ability to be useful in my job». Other material and human constraints can influence professional autonomy, such as budget reductions or a lack of computers or pedagogic books. Despite the increase in student numbers, the number of teachers has not increased more than administrative staff. This leads some to complain about «administrative shambles», as one respondent explains: "Concretely, on the ground, the absence of organization concerning students" registration greatly disturbs our work all year long». All these elements denote the fact that TPA is a component of teaching pleasure, but material conditions and relations with students can reduce it or hamper it in a quite significant way.

\section{Conclusion}

What we can conclude from all these elements about TPA is that they all confirm the definition suggested by one colleague: "autonomy is power". What meaning can we give to this expression: the power of being able to control or the power of being able to give control? Apparently both! Indeed, contrary to what people usually think, autonomy with no control at all does not seem relevant. Besides, from the survey it was made clear that for our colleagues, autonomy with no work recognition is not worth it either. Finally, autonomy with no human relation is obviously sterile. However, it is noteworthy that despite all these constraints and limits, autonomy remains essential, as one of our colleagues confirms, "autonomy: one of the reasons why I chose this job". This last remark legitimizes the need of such a reflection on TPA in France. Our results offer a much more complex answer than we originally thought. Our modest attempt of definition will need to be sharpened in future studies.

Indeed, our results point out that Teachers' Professional Autonomy is clearly a multiple canal reality at the crossroads of Social Sciences and Humanities. Developing one's autonomy is in fact developing a multitude of competences, which are part of its structure. Nevertheless, it seems hard to evaluate and acquire in the framework of one single training, especially because as we showed it a lot of elements do not depend directly on teachers. The latter will always have to endure external constraints, which 
they cannot control, and they will need to adapt to these to improve teacher training sessions and, more especially, those of Higher Education teachers. After this study, we have realized that to improve teachers' professional training in France, we need to define specific characteristics, which make a teacher professionally autonomous, as TPA is not one skill on its own; it includes several abilities, such as adaptability, initiative, risk-taking, time management, etc. We are confident that our ongoing reflection on Teachers' Professional Autonomy will contribute to making it a real professional skill for Tomorrow's University.

\section{References}

Beijaard, D.; Meijer, P. C.; Morine-Dershimer, G. and Tillema, H. Teacher Professional Development in Changing Conditions. Dordrecht: Springer, 2005.

Benson, P. and Voller, P. Autonomy and Independence in Language Learning. London: Longman, 1997.

Castany, J. and Méard, J. L'Autonomie de l'Enseignant. Geneva: Cahiers Pédagogiques 384, 2000.

Duke, D. Teacher Evaluation Policy: from Accountability to Professional Development. New York: State University of New York Press, 1995.

Edge, J. and Richards, K. Teachers Develop Teachers Research. London: Heinemann, 1993.

Elliott, J. Reconstructing Teacher Education: Teacher Development. London/Washington: The Falmer Press, 1993.

European Council. Eurydice Report: 'Responsabilités et Autonomie des Enseignants en Europe’. 2008 [interactive]. [accessed on 20-02-2013). <http:// eacea.ec.europa.eu/education/eurydice/ documents/thematic_reports/ 094FR.pdf $>$.

Freidson, E. The Professions and Their Prospects. Beverly Hills/London: SAGE Publications, 1973.

.Professional Reborn: Theory, Prophecy, and Policy. Chicago: The University of Chicago Press, 1994.
Professionalism: the Third Logic. Cambridge and Oxford: Polity, 2001.

Gavriliuk, O. Development of Professional Autonomy in University Teachers. Paper presented at Proceedings of Advances in Business-Related Scientific Research Conference, 8-10 November 2010, Olbia, Italy.

Gu, G. Teacher Development: Knowledge and Context. London: Continuum, 2007.

Lamb, T. and Reinders, H. Learner and Teacher Autonomy: Concepts, Realities and Responses. Amsterdam/Philadelphia: John Benjamins Publishing Company, 2008.

Legendre, R. Dictionnaire Actuel de l'éducation. Montreal: Guérin, 2005.

Nunan, D. Research Methods in Language Learning. Cambridge: Cambridge University Press, 1992.

. Designing Tasks for the Communicative Classroom. Cambridge: Cambridge University Press, 1989.

Observatory for Fundamental University Values and Rights. Autonomy and Responsibility. Bologna: Bonomia University Press, 2002.

Smyth, J. Critical Discourses on Teacher Development. Toronto: Continuum International Publishing Group Ltd, 1995. 


\title{
PRANCŪZIJOS AUKŠTŲJŲ MOKYKLŲ KALBŲ DE்STYTOJŲ PROFESINE AUTONOMIJA: TIES SOCIALINIŲ IR HUMANITARINIŲ MOKSLŲ SANKIRTA
}

\author{
Nadia Yassine-Diab, Nolwena Monnier \\ Paulo Sebastiero universiteto, Tulūza III, LAIRDIL tyrimų laboratorija, Prancūzija
}

Santrauka. Manoma, kad Prancüzijos universitetu sistema, lyginant su vidurinio išsilavinimo sistema, suteikia destytojams gana daug autonomijos. 2007 metu LRU istatymas, pakeitęs Prancüzijos universitetu statusa ir sudaręs salygas ju autonomijai, gali ilgalaikejje perspektyvoje paveikti ir destytoju profesinę autonomija. Ši hipoteze pastümejo mus atlikti pilotini tyrima ir nacionaline apklausa gilinantis $i$ sia tema. Straipsnyje susitelkeme ties kokybiniu tyrimo aspektu. Nacionaliniu mastu kreipemes i aukštojo mokslo kalbu dèstytojus su prašymu apiūdinti, ka jiems reiskkia profesine autonomija ir kiek ji turi įtakos dèstymui. Tai leido ižvelgti tam tikrus komandinio darbo, destytoju ir studentu santykiu ir déstytoju vertinimo bruožus. Mes aprašome, kas yra dèstytoju profesine autonomija, kas ja riboja ir kas ja išplečia socialiniu ir humanitariniu mokslu sankirtoje.

Reikšminiai žodžiai: autonomija, aukštasis mokslas, kalbų mokymas, nacionaline apklausa, profesinis rengimas.

Nadia Yassine-Diab, Paulo Sebastiero universiteto, Tulūza III, Prancūzija, LAIRDIL tyrimų laboratorijos, Technologijos instituto Kompiuterijos katedros filosofijos mokslų daktarè. Mokslinių tyrimų kryptys: anglų kaip užsienio kalba, anglų kalbos didaktika, anglų profesinė kalba, pedagogika, CLIL, dèstytojų profesinė autonomija, pokolonijinẻ literatūra, moterų literatūra, afroamerikiečių literatūra.

Nadia Yassine-Diab, Paul Sebastier University, Toulouse III, Research Laboratory LAIRDIL, Institute of Technology Computing Department (INFORMATIQUE), France, Doctor of Philology. Research interests: English as a Second Language, English Didactics, English for Specific Purposes, Pedagogy, CLIL, Teachers' professional autonomy, Postcolonial Literature, Women Literature, Black Literature.

Nolwena Monnier, Paulo Sebastiero universiteto, Tulūza III, Prancūzija, LAIRDIL tyrimų laboratorijos filosofijos mokslų daktarè. Mokslinių tyrimų kryptys: dėstytojų profesinè autonomija, CLIL, profesiniai tyrimai, tarptautiniai santykiai, viduramžių tyrimai.

Nolwena Monnier, Paul Sebastier University, Toulouse III, Research Laboratory LAIRDIL, Institute of Technology, Business Department (TC), France, Doctor of Philology. Research interests: teachers' professional autonomy, CLIL, professionalization, International relations, Medieval studies. 